\section{Lake Lappajärvi, Central Finland: a Possible Meteorite Impact Structure}

LAKE LAPPAJÄRVI (lat. $63^{\circ} 10^{\prime} \mathrm{N}$., long. $23^{\circ} 40^{\prime} \mathrm{E}$.) is situatod about $60 \mathrm{~km}$ east of Vaasa, about $200 \mathrm{~km}$ northnorth-west of Helsinki (Fig. 1). The depression in which the lake is located is largely filled by deposits from the last glaciation.

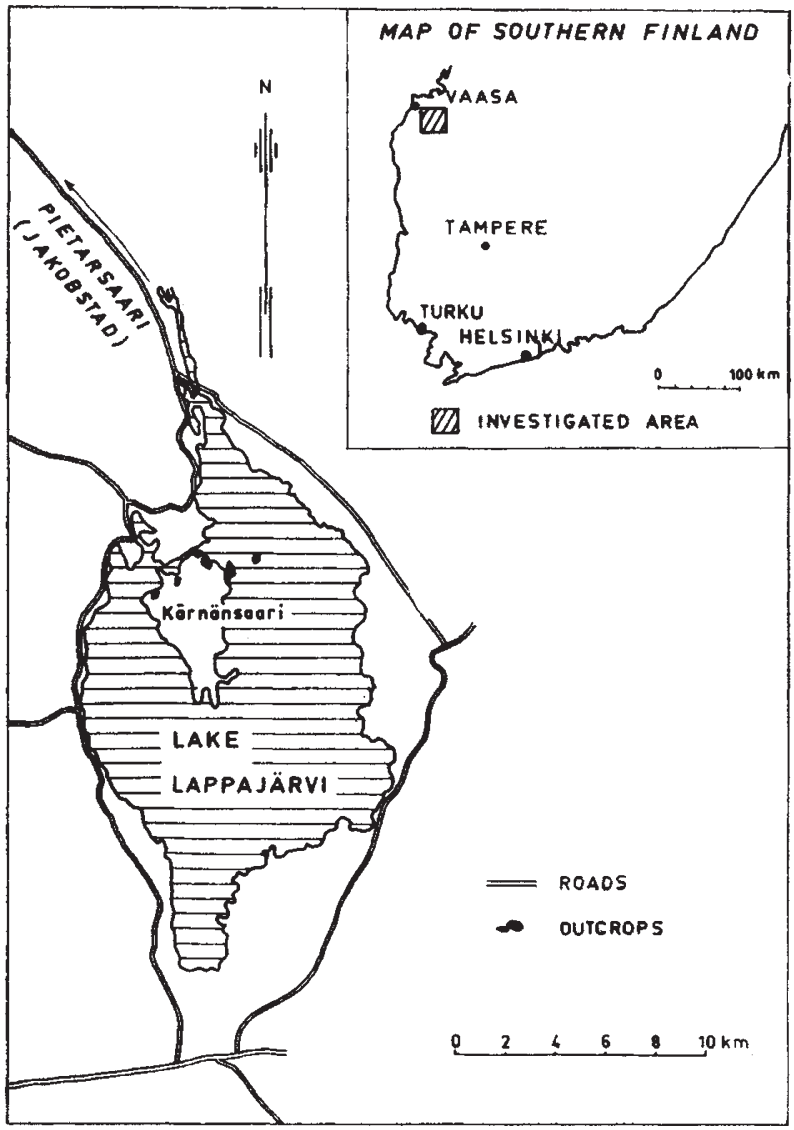

Fig. 1. Map of Lake Lappajärvi and surroundings.

Holmberg described a peculiar rock on the island of Kärnä in Lake Lappajärvi as early as 1858 (ref. 1). The rock type was called kärnäite. Outcrops have been found on the islands of Kärnänsaari and Vartijasaari in the northern part of the lake and in boulders along the southern shore-line. No kärnäite in outcrops or as blocks is known along the northernmost shores ${ }^{2}$. The bedrock around the lake is Archaeic and consists of gneisses and granites. The boulders which are found to the south of the lake are thought to come from a neck of a volcano, the upper part of which has disappeared ${ }^{3}$. Its age is probably post-Archaean but pre-Quaternary.4. The idea that the kärnäite boulders emerge from Lake Lappajärvi has been further strengthened by studies of the distribution pattern of the boulders found south of the lake ${ }^{5,6}$. The idea of a volcanic origin for the Lappajärvi structure is maintained in the most recent papers and books on the geology of Finland ${ }^{7}$. There is, however, another possible interpretation of this structure. The kärnäite boulders are similar in appearance to corresponding samples from the Ries Basin in Germany and from Lake Mien in Sweden. These structures have been interpreted as the result of the impact of meteorites ${ }^{8,9}$.

Quartz in bedrock affected by shock waves from meteorite impacts will be deformed and give quartz deform ation lamellae with definite characteristics ${ }^{10}$. These lamellae follow certain crystallographic planes, for example, (0001), (10I3) and (01I3), (10T1) and (01T1), (10I2) and (0112), the planes (10I3) and (01T3) being most common. The lamellae are also closely spaced (5 to $30 \mu$ apart) and form parallel planar features which do not transgress grain boundaries. These lamellae have been found in material from the Ries Basin and from Lake Mien ${ }^{10}$. Such lamellae have also been reported from other circular structures such as the Holleford Crater in Canada, the Meteor Crater in Arizona and the Wabar Crater in Arabia ${ }^{11,12}$.

Thin sections have been made from fragments of Archaean bedrocks in kärnäite found as boulders along the southern shoreline of Lake Lappajärvi. These have been studied under the microscope on a universal stage. The quartz grains have the same appearance as those described from the Ries Basin, Lake Mien and other similar structures. The following crystallographic planes of the lamellae have been measured (thirty-six measurements on sixteen grains): (1013) or (0113), (10I2) or $(01 \overline{1}),(21 \overline{3} 1)$ or $(12 \overline{3} 1)$, and (10I1) or (01I1). The direction (1013) or (01T3) is the most common, as von Engelhardt et al. found in the Ries Basin and in Lake Mien ${ }^{10}$. These measurements seem to support strongly the interpretation of the Lappajärvi structure as the result of meteorite impact. The size of the structure is not exactly known but must be of the order 5-6 km.

Geological Survey of Sweden,

Nils-Bertil Svensson

Department of Applied Geology and Research,

Stockholm, 50.

Received December 21, 1967 .

'Holmberg, H. J., Finska Vetenskapssocieteten, Helsinki (1858).

2 Berghell, H. in Saksela, M., CR Soc. Geol. Finland, 22, 20 (1949).

- Laitakari, A., Suomen Geologinen Yleiskartta, B 3, 39 (1942).

- Eskola, P., Bull. Comm. Geol. Finl., 55, 13 (1921).

${ }^{5}$ Mölder, K., CR Soc. Geol. Finland, 21, 50 (1948).

- Saksela, M., CR Soc. Geol. Finland, 22, 25 (1949).

7 Simonen, A., in Suomen Geologia (edit. by Rankama, K.), 115 (Kirja Yhonen, A., in Suomen Geor,

Shoemaker, E. M., and Chao, E. C. T., J. Geophys. Res., 66, 3374 (1961). ${ }^{2}$ Svensson, N. B., and Wickman, F. E., Nature, 205, 1202 (1965).

${ }^{10}$ v. Engelhardt, W., and Stöffler, D., Naturwissenschaften, 52, 489 (1965).

11 Bunch, T. E., and Cohen, A. J., Science, 142, 379 (1963).

${ }_{12}$ Bunch, T. F., and Cohen, A. J., Geol. Soc. America Bull., 75, 1263 (1964).

\section{Radiative Association : Possible Important Loss Process for Metallic Ions in the lonosphere}

THE maximum lifetime of a metallic ion, $\mathrm{M}^{+}$, in the upper atmosphere is believed to be limited by radiative recombination, $M^{+}+\mathrm{e} \rightarrow M+$ hv. The rate coefficient, $\gamma_{r}$, for this process is about (ref. 1) $3 \times 10^{-12} \mathrm{~cm}^{3} \mathrm{sec}^{-1}$ at $300^{\circ} \mathrm{K}$.

Radiative recombination should be contrasted with the loss of atomic ions through the radiative association processes

$$
\begin{aligned}
& M^{+}+\mathrm{O} \rightarrow \mathrm{MO}^{+}+\mathrm{h \nu} \\
& M^{+}+\mathrm{O}_{2} \rightarrow \mathrm{MO}_{2}^{+}+\mathrm{h \nu}
\end{aligned}
$$

Atomic nitrogen densities are too low at these altitudes for $M^{+}+\mathrm{N} \rightarrow M \mathrm{~N}^{+}+\mathrm{h} \nu$ to be important. The ion $X \mathrm{~N}_{2}^{+}$, if not unstable, is much less likely to be formed than $\mathrm{XO}^{+}$ or $\mathrm{XO}_{2}^{+}$.

Radiative association is quickly followed by dissociative recombination, with a rate coefficient of the order $3 \times 10^{-7}$ $\mathrm{cm}^{3} \mathrm{sec}^{-1}$. Thus radiative association is the rate limiting step in the neutralization of metallic ions, $M^{+} \rightarrow M X^{+}$ $\left(M X_{2}^{+}\right) \rightarrow$ neutrals.

The loss rate for each metallic ion caused by radiative recombination, $\gamma_{r}[\mathrm{e}]$, is compared in Table 1 with the radiative association loss rates $\gamma[\mathrm{O}]$ and $\left.\mathrm{\gamma}_{2} \mathrm{O}_{2}\right]$ at altitudes of interest for the ions of sodium, calcium, magnesium, potassium, silicon, iron, aluminium and nickel. The loss 